\title{
Agronomic performance of strawberry plants under growing environments and organomineral fertilization ${ }^{1}$
}

\author{
Keivia Lino Chagas ${ }^{2}$, Thales Vinícius de Araújo Viana², \\ Denise Vieira Vasconcelos ${ }^{3}$, Geocleber Gomes de Sousa ${ }^{4}$, João Valdenor Pereira Filho ${ }^{2}$
}

\section{ABSTRACT}

Organic fertilization, associated to cultivation under a climatized environment, can make profitable the growth of strawberry plants in the Brazilian Northeast region, increasing the market value for their fruits. This study aimed to evaluate the effect of organic and/or mineral fertilization on strawberry plants grown under different environments. The experiment was carried out in a complete split-plot randomized block design, with four replications. The plots were composed by three cultivation environments and the subplots by six types of fertilization, associating mineral and organic fertilization. The organomineral fertilization with equal proportions of bovine manure and NPK mineral fertilizer provides a higher number of fruits per plant, average fruit mass per plant, yield and fruit length. There was no significant difference among the evaluated environments; however, in general, the climatized environment provides greater results, regarding the development and quality of the plants, improving the physicochemical characteristics of the fruits.

KEYWORDS: Fragaria x Ananassa Duch.; biofertilizers; plant nutrition.

\section{INTRODUCTION}

Over the past decade, the high demand for strawberry (Fragaria $x$ ananassa Duch.) resulted in one of the greatest increases in the consumption of this fruit (Sousa et al. 2014). Approximately 4.5 million tons of strawberries are produced annually worldwide (FAO 2017). Europe and the Americas lead with $74 \%$ of the total production, followed by Asia (16\%), Africa (9\%) and Oceania $(1 \%)$.

\section{RESUMO}

Desempenho agronômico de morangueiro sob ambientes de cultivo e adubação organomineral

A fertilização orgânica, associada ao cultivo em ambiente climatizado, pode tornar rentável o cultivo de morangueiro no Nordeste brasileiro, fazendo-o alcançar grande valor de mercado. Objetivou-se avaliar o efeito da adubação orgânica e/ou mineral sobre morangueiros cultivados em diferentes ambientes. $\mathrm{O}$ experimento foi desenvolvido em delineamento de blocos ao acaso, com parcelas subdivididas e quatro repetições. As parcelas foram compostas por três ambientes de cultivo e as subparcelas por seis tipos de fertilização, por meio da associação entre adubação mineral e orgânica. A adubação organomineral com proporções iguais de esterco bovino e adubo mineral NPK proporciona maior número de frutos por planta, massa média de frutos por planta, produtividade e comprimento dos frutos. Não houve diferença significativa entre os ambientes avaliados; no entanto, de maneira geral, o ambiente climatizado proporciona maiores resultados, quanto ao desenvolvimento e à qualidade das plantas, melhorando as características físico-químicas dos frutos.

PALAVRAS-CHAVE: Fragaria $x$ Ananassa Duch.; biofertilizantes; nutrição de plantas.

Brazil is not among the world's largest producers; however, the average crop yield is $30 \mathrm{t} \mathrm{ha}^{-1}$, and could reach over $60 \mathrm{t} \mathrm{ha}^{-1}$, in more technified places (Reisser Júnior et al. 2015). Strawberries are grown mainly in the states of Minas Gerais, Rio Grande do Sul, São Paulo and Paraná (Costa et al. 2011), and are considered to be of economic importance to the country.

In the Brazilian Northeast region, the production has been limited to a few mountainous areas, such as Maciço de Baturité, Chapada da Ibiapaba and

1. Received: May 07, 2018. Accepted: Jun. 27, 2018. Published: Oct. 01, 2018. DOI: 10.1590/1983-40632018v4852876.

2. Universidade Federal do Ceará, Departamento de Engenharia Agrícola, Fortaleza, CE, Brasil. E-mail/ORCID: kei-via@hotmail.com/ 0000-0002-1293-6637, thales@ufc.br/0000-0003-0722-6371,joao_valdenor@hotmail.com/0000-0001-9018-5755.

3. Instituto Federal de Educação, Ciência e Tecnologia do Pará, Bragança, PA, Brasil. E-mail/ORCID: denisevasconcelos@hotmail.com/0000-0002-3298-4812.

4. Universidade da Integração Internacional da Lusofonia Afro-Brasileira, Instituto de Desenvolvimento Rural, Redenção, CE, Brasil.E-mail/ORCID: sousagg@unilab.edu.br/0000-0002-1466-6458. 
Chapada do Araripe, as well as Meruoca, during the autumn and winter seasons. An alternative for strawberry cultivation in other northeastern regions, therefore, would be the use of air-conditioned environments, that can artificially approximate the local microclimatic conditions, especially air temperature, of those in the main producing regions of the country. It should be emphasized that the high temperatures in the Northeast region can inhibit the growth of the pollen tube and reduce the growth, development and production of strawberry fruits (Kadir et al. 2006, Lima et al. 2018).

Another important consideration in the growth of strawberries is the high percentage of mineral components required, which can be reduced by the use of organic mineral fertilization. This technique consists in replacing chemical fertilizers by liquid biofertilizers, showing to be an effective way of providing essential nutrients to the plant (Leonel et al. 2015).

The use of organic residue composts, crop residues and liquid biofertilizing stand out as alternatives in the search for components which fertilize with less aggression to the environment, reducing the use of mineral fertilization and especially the use of pest and disease controls (Rodolfo Junior et al. 2008). The importance of biofertilization is in the diversity of mineral nutrients chelated and provided by the biological activity and as enzyme activators of the plant metabolism (Sá et al. 2015).

This study aimed at analyzing the effect of organic and/or mineral fertilization on strawberry plants grown under different environments.

\section{MATERIAL AND METHODS}

The study was carried out in an experimental area of the Universidade Federal do Ceará, in Fortaleza, Ceará state, Brazil ( $3^{\circ} 45^{\prime} \mathrm{S}, 38^{\circ} 33^{\prime} \mathrm{W}$ and altitude of $19 \mathrm{~m}$ ), from June to October 2016. The local climate is Aw', with an annual rainfall of $1,564 \mathrm{~mm}$, average temperature of $27^{\circ} \mathrm{C}$ and an average relative air humidity of $78 \%$, according to data from the local weather station.

The micro-climatic conditions of the experimental area, in each cultivation environment, were monitored by data-logger equipment. The average monthly information for the meteorological variables were collected during the experimental period in the environments A1 (protected airconditioned environment), A2 (open air, with no solar protection) and A3 (shaded environment, with a solar protection screen - $70 \%$ ) (Table 1).

The soil presented the following chemical characteristics: organic matter $=19.16 \mathrm{~g} \mathrm{~kg}^{-1}$; $\mathrm{N}=0.16 \mathrm{mmol}_{\mathrm{c}} \mathrm{dm}^{-3} ; \mathrm{Ca}=26.3 \mathrm{mmol}_{\mathrm{c}} \mathrm{dm}^{-3}$; $\mathrm{K}=0.11 \mathrm{mmol}_{\mathrm{c}} \mathrm{dm}^{-3} ; \mathrm{Mg}=25.6 \mathrm{mmol}_{\mathrm{c}} \mathrm{dm}^{-3}$; $\mathrm{Na}=45 \mathrm{mmol}_{\mathrm{c}} \mathrm{dm}^{-3} ; \mathrm{H}+\mathrm{Al}=19 \mathrm{mmol}_{\mathrm{c}} \mathrm{dm}^{-3}$; sum of bases $=105.7 \mathrm{mmol}_{\mathrm{c}} \mathrm{dm}^{-3}$; cation exchange capacity $=124.7 \mathrm{mmol}_{\mathrm{c}} \mathrm{dm}^{-3}$; base saturation $=85 \%$; $\mathrm{P}=0.34 \mathrm{mg} \mathrm{dm}^{-3}$; and $\mathrm{pH}=6.9$.

The used seedlings (Oso Grande cultivar) were transplanted to flexible plastic pots $\left(2\right.$ pot $\left.^{-1}\right)$, with a volume capacity of $10 \mathrm{~L}$ (containing soil and organic compost, in a proportion of $3: 1$, respectively), at 25 days after sowing.

The experiment was carried out in a complete split-plot randomized block design, with four replications. The plots consisted of three cultivation environments, denominated: A1 - protected airconditioned environment (consisting of an antiaphid shield on the outside and a waterproof plastic covering inside, in the white color, and two airconditioners to balance and keep the temperature cool); A2 - full sun, with no solar protection; A3 shaded environment, with a solar protection screen $(70 \%)$. The subplots were divided into six types of fertilization: T1 - mineral fertilizer $(50 \%)+$ caprine biofertilizer $(50 \%)$; T2 - mineral fertilizer $(50 \%)+$ bovine biofertilizer (50\%); T3 - bovine biofertilizer $(100 \%)$; T4 - caprine biofertilizer (100\%);

Table 1. Air temperature $\left(\mathrm{Ta},{ }^{\circ} \mathrm{C}\right)$ and relative humidity $(\mathrm{RH}, \%)$, during the research period with strawberry, from different experimental environments.

\begin{tabular}{lcccccc}
\hline \multirow{2}{*}{ Month } & \multicolumn{2}{c}{ A1 (air-conditioned) } & \multicolumn{2}{c}{ A2 (full sun) } & \multicolumn{2}{c}{ A3 (shaded - 70 \%) } \\
\cline { 2 - 7 } & Ta & RH & Ta & RH & Ta & RH \\
\hline June & 23.9 & 68.7 & 31.0 & 71.7 & 28.4 & 80.1 \\
July & 23.7 & 67.3 & 31.2 & 71.2 & 28.1 & 82.6 \\
August & 24.1 & 68.9 & 31.9 & 69.5 & 27.8 & 84.9 \\
September & 24.1 & 69.0 & 31.0 & 69.1 & 27.9 & 84.3 \\
\hline
\end{tabular}


T5 - mineral fertilizer (100\%); T6 - control (no fertilizer).

The bovine and caprine biofertilizers were produced in a 1:1 proportion, based on volume, using their respective fresh manure and water. They were then put into 1,000 L tanks, leaving the blend to ferment aerobically during 30 days, when it was ready to use.

The biofertilizers (bovine and caprine; Table 2) were applied manually once a week, in the following proportions, in accordance to the treatments: $100 \%=$ $1,000 \mathrm{~mL}^{\text {week }}{ }^{-1}$ plant $^{-1}$; and $50 \%=500 \mathrm{~mL}^{\text {week }}{ }^{-1}$ plant $^{-1}$.

The maximum recommendation for chemical adduction was followed in order to meet the strawberries nutritional needs, as stipulated by Santos \& Medeiros (2005), corresponding to $180 \mathrm{~kg} \mathrm{ha}^{-1}$ of $\mathrm{N}, 300 \mathrm{~kg} \mathrm{ha}^{-1}$ of $\mathrm{P}_{2} \mathrm{O}_{5}$ and $100 \mathrm{~kg} \mathrm{ha}^{-1}$ of $\mathrm{K}_{2} \mathrm{O}$. As a reference, for a stand of 12,500 plants (spaced at $0.3 \mathrm{~m} \times 0.3 \mathrm{~m}$ ), the maximum dose recommended for the plant cycle would be $14.4 \mathrm{~g}$ of $\mathrm{N}, 24 \mathrm{~g}$ of $\mathrm{P}_{2} \mathrm{O}_{5}$ and $8 \mathrm{~g}$ of $\mathrm{K}_{2} \mathrm{O}$.

The amount of nutrients found in the substrate was calculated as it follows: 1.3 (soil density) x $10 \mathrm{~L}$ $($ volume of soil in each pot $)=13 \mathrm{~kg} \mathrm{pot}^{-1}$ of soil $\mathrm{x}$ amount of N, P and $\mathrm{K}$ present in the substrate analysis (Table 3).

A localized drip system was used for irrigation, which was dimensioned to operate with selfcompensating drip dispensers, with one outlet per pot and a nominal flow rate of $8 \mathrm{~L} \mathrm{~h}^{-1}$. The drip dispensers were previously tested under normal operating conditions (Keller \& Karmelli 1975). At that time, the irrigation systems presented a coefficient of uniformity distribution of approximately $90 \%$, in the three cultivated environments.

The irrigation time for the cultivation environments was quantified using the following equation: $\mathrm{IT}=60 *(\mathrm{Af} * \mathrm{ECA} * \mathrm{Kp} * \mathrm{Kc} * \mathrm{~Pa}) /$ $\left(\right.$ Ie $* \mathrm{q}_{\mathrm{i}}$ ), where $I T$ is the irrigation time $(\mathrm{min}) ; A f$ the adjustment factor (internal ECA/external ECA); $E C A$ the evaporation measured in the Class A tank
Table 3. Estimated nutrient supply by substrate and nutritional supplementation needs.

\begin{tabular}{|c|c|c|c|}
\hline \multirow{2}{*}{ Chemical characteristics } & \multicolumn{3}{|c|}{ Nutrient } \\
\hline & $\mathrm{N}$ & $\mathrm{P}$ & K \\
\hline \multirow{2}{*}{ Recommendation } & \multicolumn{3}{|c|}{$\left(\right.$ g plant $\left.^{-1}\right)$} \\
\hline & 14.40 & 24.00 & 8.00 \\
\hline \multirow{4}{*}{ Substrate } & \multicolumn{3}{|c|}{$\left(\mathrm{g} \mathrm{kg}^{-1}\right)$} \\
\hline & 0.16 & 0.34 & 0.11 \\
\hline & \multicolumn{3}{|c|}{$\left(13 \mathrm{~kg} \mathrm{plant}^{-1}\right)$} \\
\hline & 2.08 & 4.42 & 1.43 \\
\hline \multirow{2}{*}{ Supplementary nutrition } & \multicolumn{3}{|c|}{$\left(\right.$ g plant $\left.^{-1}\right)$} \\
\hline & 12.32 & 19.58 & 6.57 \\
\hline Need of biofertilizer for complementation & \multicolumn{3}{|c|}{$\left(\mathrm{L} \mathrm{plant}^{-1}\right)$} \\
\hline Bovine & 15.02 & 13.98 & 6.57 \\
\hline Caprine & 20.19 & 61.18 & 1.93 \\
\hline
\end{tabular}

$(\mathrm{mm}) ; K p$ the tank coefficient (dimensionless); $K c$ the cultivation coefficient (dimensionless); $\mathrm{Pa}$ the pot area $\left(\mathrm{m}^{2}\right)$; Ie the irrigation efficiency $(0.90)$; and $q_{i}$ the pot flow rate $\left(\mathrm{L} \mathrm{h}^{-1}\right)$.

An adjustment factor of 1.0 was used to determine the irrigation time for the open air environment (A2). For the shaded environment (A3), the adjustment factor was 0.8 , while 0.6 was used for the air-conditioned environment (A1). Watering was carried out daily, and the ECA measurements were quantified by means of a Class A tank installed at approximately $35 \mathrm{~m}$ from the experiment areas.

The harvest was only accomplished for the strawberries that showed to be $3 / 4$ ripe or that had an intense red color (Camargo et al. 2009). To determine the total production, the harvested strawberries were counted and weighed.

The production characteristics evaluated were: total strawberries per plant, determined by adding the total strawberries in a given plot and then dividing by the number of plants in the same plot; yield, represented by the average production of fruit per area and expressed as $\mathrm{kg} \mathrm{ha}^{-1}$, accumulated during the different stages of the harvest; and average fruit mass, weighed on digital scales, on the dates of each harvest.

Table 2. Composition of macro and essential micronutrients in the dry matter of bovine and caprine biofertilizers.

\begin{tabular}{|c|c|c|c|c|c|c|c|c|c|c|c|}
\hline \multirow{3}{*}{ Biofertilizer } & \multicolumn{11}{|c|}{ Mineral elements } \\
\hline & $\mathrm{N}$ & $\mathrm{P}$ & K & $\mathrm{Ca}$ & $\mathrm{Mg}$ & $\mathrm{S}$ & $\mathrm{Na}$ & $\mathrm{Fe}$ & $\mathrm{Cu}$ & $\mathrm{Zn}$ & $\mathrm{Mn}$ \\
\hline & \multicolumn{7}{|c|}{$-\mathrm{g} \mathrm{L}^{-1}$} & \multicolumn{4}{|c|}{$\mathrm{mg} \mathrm{L}^{-1}$} \\
\hline Bovine & 0.82 & 1.40 & 1.0 & 2.5 & 0.75 & 0.31 & 0.28 & 141.60 & 1.92 & 68.2 & 14.72 \\
\hline Caprine & 0.61 & 0.32 & 3.4 & 2.7 & 0.85 & 0.42 & 0.38 & 175.98 & 1.89 & 64.5 & 12.45 \\
\hline
\end{tabular}


The post-harvest variables analyzed were: soluble solids content, expressed in ${ }^{\circ} \mathrm{Brix}$, determined from the amount of juice extracted from the collected samples, with the juice obtained by hand squeezing, with results obtained with a direct reading refractometer (Digital refractometer $\mathrm{PAL}^{-1}$ - ATAGO); fruit diameter, measured with a digital pachymeter; and strawberry length, also measured with a digital pachymeter.

The results of the different environments and fertilizers were evaluated using analysis of variance (Anova). When the $\mathrm{F}$ test results were significant, they were further tested with the Tukey test, at $5 \%$ and $1 \%$ of significance, using the Assistant 7.6 Beta software.

\section{RESULTS AND DISCUSSION}

The interaction between fertilizers and cultivation environments significantly influenced all variables analyzed, except for the soluble solids content (Table 4).
The largest average mass for the strawberries (16.10 g plant $\left.^{-1}\right)$ resulted from fertilization with mineral fertilizer + bovine biofertilizer (T2), in the air-conditioned environment (A1). Nevertheless, the results were not significantly different from the ones obtained in the full sun $\left(10.80 \mathrm{~g} \mathrm{plant}^{-1}\right)$ and shaded (12.97 g plant $^{-1}$ ) environments (Table 5).

Camargo et al. (2009) evaluated the average fruit mass of eight types of strawberry (Aromas, Camino Real, Campinas, Dover, Oso Grande, Toyonaka, Tudla-Milsei and Ventana), grown conventionally and organically, and found values of $13.64 \mathrm{~g}$ (Tudla-Milsei), $13.01 \mathrm{~g}$ (Ventana) and $11.69 \mathrm{~g}$ (Camino Real) for organic strawberries.

The average values resulting from the interaction between fertilization and environments, for number of fruits per plant, are available in Table 6 . The highest average value was observed for the cultivation with organic mineral fertilization in the air-conditioned environment (21.66 units). Nevertheless, this result did not differ statistically

Table 4. Summary of the analysis of variance and significance levels for the average fruit mass per plot (AFMP), number of strawberries per plot (NSP), yield (Y), soluble solids content (SS), fruit diameter (FD) and fruit length (FL) for strawberries cultivated in different environments, using different fertilizers.

\begin{tabular}{lccccccc}
\hline \multirow{2}{*}{ Source of variation } & \multicolumn{9}{c}{ Average square } \\
\cline { 2 - 7 } & DF & AFMP & NSP & Y & FL & FD & SS \\
\hline Fertilizations (A) & 5 & $124.66^{* *}$ & $364.73^{* * *}$ & $221.63^{* *}$ & $1,309.00^{* *}$ & $652.08^{* *}$ & $22.27^{* *}$ \\
Residue (a) & 18 & 5.84 & 17.12 & 10.39 & 24.79 & 7.20 & 1.20 \\
Plots & 23 & - & - & - & - & - & - \\
Environments (B) & 2 & $81.16^{* *}$ & $104.42^{*}$ & $144.28^{* *}$ & $203.35^{*}$ & $104.42^{*}$ & $12.33^{* *}$ \\
Interaction A x B & 10 & $3.19^{*}$ & $3.7^{* *}$ & $5.67^{*}$ & $5.53^{* *}$ & $4.98^{*}$ & $0.76^{\text {ns }}$ \\
Residue (b) & 36 & 14.53 & 21.18 & 25.84 & 59.20 & 22.35 & 1.97 \\
\hline Total & 71 & $1,446.16$ & $3,140.31$ & $2,570.96$ & $9,584.93$ & $4,453.60$ & 226.58 \\
\hline CVa (\%) & - & 24.93 & 37.25 & 24.93 & 17.19 & 11.06 & 18.16 \\
\hline CVb (\%) & - & 39.31 & 41.41 & 39.31 & 26.56 & 19.48 & 23.21 \\
\hline
\end{tabular}

$*$ and $* *$ significant at $5 \%$ and $1 \%$, respectively, by the $\mathrm{F}$ test.

Table 5. Average fruit mass per plant (AFMP) values for strawberries cultivated with organic mineral fertilizers, in different environments, at 120 days after transplanting.

\begin{tabular}{|c|c|c|c|}
\hline $\operatorname{AFMP}\left(\right.$ g plant $\left.^{-1}\right)$ & \multicolumn{3}{|c|}{ Environments } \\
\hline Fertilizations & A1 (air-conditioned) & A2 (full sun) & A3 (shaded) \\
\hline $\mathrm{T} 1(50 \%$ mineral $+50 \%$ caprine $)$ & $16.07 \mathrm{aA}^{*}$ & $10.60 \mathrm{aA}$ & $12.87 \mathrm{aA}$ \\
\hline $\mathrm{T} 2(50 \%$ mineral $+50 \%$ bovine $)$ & $16.10 \mathrm{aA}$ & $10.80 \mathrm{aA}$ & $12.97 \mathrm{aA}$ \\
\hline T3 (100\% bovine biofertilization) & $12.08 \mathrm{bA}$ & $8.60 \mathrm{aA}$ & $5.77 \mathrm{bcA}$ \\
\hline T4 (100 \% caprine biofertilization) & $7.40 \mathrm{bcA}$ & $5.35 \mathrm{aA}$ & $9.57 \mathrm{bA}$ \\
\hline T5 (100\% mineral fertilization) & $11.92 \mathrm{bA}$ & $8.60 \mathrm{aA}$ & $8.03 \mathrm{bA}$ \\
\hline T6 (control) & $6.90 \mathrm{bcA}$ & $5.30 \mathrm{aA}$ & $5.47 \mathrm{bcA}$ \\
\hline
\end{tabular}

\footnotetext{
* Using the Tukey test, at $5 \%$ of probability, no statistical difference was found between the averages followed by the same lowercase letter in the column and capital
} letter in the row. $\mathrm{MSD}_{\mathrm{C}}$ and $\mathrm{MSD}_{\mathrm{R}}$ - minimum significant difference in the columns and rows, respectively; GA: general average. 
from those found in the environments A2 (14.55 units) and A3 (16.81 units). Likewise, Dias et al. (2015) found no significant difference in the results obtained for strawberries cultivated in two environments (screened and open field).

The effect of organic fertilization on the amount of fruits produced per plant was also confirmed by Dutra et al. (2016), who verified a proportional raise in the number of watermelons grown with an increase in the organic fertilizer. This result shows the positive effect of organic fertilization, corroborating those of the current research, in which the application of biofertilizers added to mineral fertilizers increased the production.

The average values resulting from the interaction between fertilization and environments, as relating to yield, are shown in Table 7. The highest average production $\left(21.46 \mathrm{t} \mathrm{ha}^{-1}\right)$ was attained by mixing mineral fertilizer with bovine biofertilizer (T2), in an air-conditioned environment (A1). This greater yield may be related to an adequate supply and availability of nutrients supplied by the organic fertilization, since, in those cases, where only biofertilizers were applied (T3 and T4, for example), there was no increase in yield. According to Oliveira et al. (2009), high levels of manure may cause a nutritional imbalance in the soil, reducing the crop development and total yield.

Adequate levels of nitrogen, phosphorus and potassium increase significantly the strawberry production, especially in fertile soil, improving the strawberry size, shape and weight, as well as its flavor, aroma, color and consistency (Vignolo et al. 2011). This may explain the results obtained in tests T1 and T2 (combination of mineral fertilizer and biofertilizer), as these experiments resulted in a greater yield, probably because they provided a more appropriate nutrition.

Summarizing, the values were higher for all the production variables (average fruit mass per plant, number of fruits per plant and yield), when using organic mineral fertilization in plants cultivated in the air-conditioned environment. Many studies have shown the positive effects of the interaction between organic and mineral fertilization on various types of fruits, which resulted in a significant increase in the

Table 6. Average values for total number of strawberries per plant (NSP), using organic mineral fertilizers in different environments.

\begin{tabular}{lccc}
\hline \multicolumn{1}{c}{ NSP } & \multicolumn{3}{c}{ Environment } \\
\hline Fertilizations & A1 (air-conditioned) & A2 (full sun) & A3 (shaded) \\
\hline T1 $(50 \%$ mineral $+50 \%$ caprine) & $19.76 \mathrm{aA}$ & $14.4 \mathrm{aA}$ & $16.36 \mathrm{aA}$ \\
T2 $(50 \%$ mineral $+50 \%$ bovine) & $21.66 \mathrm{aA}$ & $14.55 \mathrm{aA}$ & $16.81 \mathrm{aA}$ \\
T3 (100\% bovine biofertilization) & $13.15 \mathrm{bA}$ & $10.06 \mathrm{bA}$ & $10.45 \mathrm{bA}$ \\
T4 (100\% caprine biofertilization) & $13.22 \mathrm{bA}$ & $9.66 \mathrm{bA}$ & $10.18 \mathrm{bA}$ \\
T5 (100\% mineral fertilization) & $6.57 \mathrm{bA}$ & $4.32 \mathrm{bA}$ & $4.17 \mathrm{bA}$ \\
T6 (control) & $6.45 \mathrm{bA}$ & $4.02 \mathrm{bA}$ & $4.12 \mathrm{bA}$ \\
\hline & MSDc 9.29 & MSDR 7.94 & GA 11.10 \\
\hline
\end{tabular}

* Using the Tukey test, at $5 \%$ of probability, no statistical difference was found between the averages followed by the same lowercase letter in the column and capital letter in the row. $\mathrm{MSD}_{\mathrm{C}}$ and $\mathrm{MSD}_{\mathrm{R}}$ - minimum significant difference in the columns and rows, respectively; GA: general average.

Table 7. Average yield for the strawberry crop using organic mineral fertilizers in different environments.

\begin{tabular}{lccc}
\hline \multicolumn{2}{c}{${\text { Yield }\left(\mathrm{t} \mathrm{ha}^{-1}\right)}^{\text {Fertilizations }}$} & \multicolumn{3}{c}{ Environments } \\
\hline T1 $(50 \%$ mineral $+50 \%$ caprine) & A1 (air-conditioned) & A2 (full sun) & A3 (shaded) \\
T2 (50\% mineral $+50 \%$ bovine) & $21.43 \mathrm{aA}^{*}$ & $14.13 \mathrm{aA}$ & $17.16 \mathrm{aA}$ \\
T3 (100\% bovine biofertilization) & $21.46 \mathrm{aA}$ & $14.40 \mathrm{aA}$ & $17.30 \mathrm{aA}$ \\
T4 (100\% caprine biofertilization) & $16.11 \mathrm{bA}$ & $11.57 \mathrm{aA}$ & $12.76 \mathrm{bA}$ \\
T5 (100\% mineral fertilization) & $15.90 \mathrm{bA}$ & $11.47 \mathrm{aA}$ & $10.71 \mathrm{bA}$ \\
T6 (control) & $9.93 \mathrm{bA}$ & $7.13 \mathrm{aA}$ & $7.70 \mathrm{cA}$ \\
\hline MSDc 9.54 & $9.23 \mathrm{bA}$ & $7.06 \mathrm{aA}$ & $7.30 \mathrm{cA}$ \\
\hline
\end{tabular}

* Using the Tukey test, at $5 \%$ of probability, no statistical difference was found between the averages followed by the same lowercase letter in the column and capital letter in the row. $\mathrm{MSD}_{\mathrm{C}}$ and $\mathrm{MSD}_{\mathrm{R}}$ - minimum significant difference in the columns and rows, respectively; GA: general average. 
average fruit mass for strawberry, with an average value of 17.4 g plant $^{-1}$ (Schuch \& Barros 2010 ); in the amount of total pepper fruits, with an average value of 1.2 (x1000) (Sediyama et al. 2009); and total commercial yield of tomato, with an average value of 25,405.4 $\mathrm{kg} \mathrm{ha}^{-1}$ (Luz et al. 2010).

Results obtained by Dias et al. (2015), with Oso Grande strawberries, in handcrafted screened and open field environments, using a liquid biofertilizer, verified maximum yields of $10.734 \mathrm{~kg} \mathrm{ha}^{-1}$ and $9.629 \mathrm{~kg} \mathrm{ha}^{-1}$, respectively, considered lower results, when compared to those obtained in the airconditioned and shaded environments evaluated in the current study.

The increase in the production variables, in the treatments with organic mineral fertilization, can be justified according to Toledo et al. (2017), due to the fact that higher nutritional levels result in higher photosynthesis rates, which, in turn, result in larger amounts of carbohydrates being assigned to the plant storage areas, with a consequent increase in fruit weight. Other factors also influence this variable, such as environmental factors, mainly temperature and photoperiod and their interactions, which play an important role in the growth, development and production of strawberries (Rosa et al. 2013).

The average values for the interaction between fertilizers and environments, in relation to the post-harvest fruit length, are shown in Table 8 . The most expressive value $(44.57 \mathrm{~mm})$ resulted from fertilization with mineral fertilizer and bovine biofertilizer (T2), in an air-conditioned environment (A1). The smallest value $(15.67 \mathrm{~mm})$ resulted from the full sun cultivation. The obtained results confirm that the air-conditioned environment provides the most appropriate microclimate, close to ideal, for the productive development of strawberries (Bortollozo et al. 2007). Yuri et al. (2012) studied the fruit length under different types of mulching and found that cultivating Oso Grande strawberries under white film resulted in a length of $29.10 \mathrm{~mm}$.

Mueller et al. (2013) corroborate the results of the current study and reported that the use of biofertilizers is important, as they act upon the fertility of the systems. This is not due to the number of nutrients, but to the diversity of the mineral composition, which form chelated composts resulting from the biological activity and act as enzymatic activators of the fruit metabolism.

The average diameters for the strawberries cultivated with different fertilizers, in different environments, are shown in Table 9. The highest average resulted from the interaction between mineral fertilizer and caprine biofertilizer (T1), in an airconditioned environment (A1). The smallest diameter $(14.49 \mathrm{~mm})$ was also observed in the full sun control treatment. Dias et al. (2015) found that the biofertilizer dose had no significant influence on the diameter of strawberries cultivated in screened and open field environments. The authors cited found an average diameter of $23.70 \mathrm{~mm}$, justified by physiological and genetic factors, which are altered by climate conditions and interfere directly on flowering and fruit development (Camargo et al. 2010).

Similar results were obtained by Almeida et al. (2015), with an average diameter of $29.00 \mathrm{~mm}$, in different cultivation environments. According to these authors, plants grown under a protected environment (air-conditioned) are healthier and more intense, because the climatic conditions and the fertilizers allow a greater interaction with the physiological activities, during the fruiting stage.

Table 8. Average values for the strawberries fruit length with organic mineral fertilization in different environments.

\begin{tabular}{|c|c|c|c|}
\hline Fruit length (mm) & \multicolumn{3}{|c|}{ Environments } \\
\hline Fertilizations & A1 (air-conditioned) & A2 (full sun) & A3 (shaded) \\
\hline $\mathrm{T} 1$ (50\% mineral $+50 \%$ caprine $)$ & $44.25 \mathrm{aA}^{*}$ & $37.20 \mathrm{aA}$ & $37.90 \mathrm{aA}$ \\
\hline $\mathrm{T} 2(50 \%$ mineral $+50 \%$ bovine $)$ & $44.57 \mathrm{aA}$ & $37.25 \mathrm{aA}$ & $37.97 \mathrm{aA}$ \\
\hline T3 (100\% bovine biofertilization) & $34.52 \mathrm{aA}$ & $28.81 \mathrm{aA}$ & $28.75 \mathrm{aA}$ \\
\hline T4 (100\% caprine biofertilization) & $33.94 \mathrm{aA}$ & $28.16 \mathrm{aA}$ & $28.22 \mathrm{aA}$ \\
\hline T5 (100 \% mineral fertilization) & $18.60 \mathrm{bA}$ & $15.86 \mathrm{bA}$ & $15.94 \mathrm{bA}$ \\
\hline T6 (control) & $18.06 \mathrm{bA}$ & $15.67 \mathrm{bA}$ & $15.69 \mathrm{bA}$ \\
\hline $\mathrm{MSD}_{\mathrm{C}} 14.49$ & $\mathrm{MSD}_{\mathrm{R}} 13.28$ & & GA 28.96 \\
\hline
\end{tabular}

* Using the Tukey test, at $5 \%$ of probability, no statistical difference was found between the averages followed by the same lowercase letter in the column and capital letter in the row. $\mathrm{MSD}_{C}$ and $\mathrm{MSD}_{\mathrm{R}}$ - minimum significant difference in the columns and rows, respectively; GA: general average. 
Table 9. Average fruit diameter of strawberries with organic mineral fertilization in different environments.

\begin{tabular}{|c|c|c|c|}
\hline Fruit diameter $(\mathrm{mm})$ & \multicolumn{3}{|c|}{ Environments } \\
\hline Fertilizations & A1 (air-conditioned) & A2 (open air) & A3 (shaded) \\
\hline $\mathrm{T} 1$ (50\% mineral $+50 \%$ caprine $)$ & $35.34 \mathrm{aA}^{*}$ & $28.52 \mathrm{aA}$ & $32.00 \mathrm{aA}$ \\
\hline $\mathrm{T} 2(50 \%$ mineral $+50 \%$ bovine $)$ & $35.29 \mathrm{aA}$ & $28.55 \mathrm{aA}$ & $32.14 \mathrm{aA}$ \\
\hline T3 (100 \% bovine biofertilization) & $27.61 \mathrm{aA}$ & $24.34 \mathrm{aA}$ & $24.37 \mathrm{aA}$ \\
\hline T4 (100\% caprine biofertilization) & $26.66 \mathrm{aA}$ & $23.65 \mathrm{aA}$ & $24.37 \mathrm{aA}$ \\
\hline T5 (100 \% mineral fertilization) & $17.12 \mathrm{bA}$ & $14.81 \mathrm{bA}$ & $15.11 \mathrm{bA}$ \\
\hline T6 (control) & $17.08 \mathrm{bA}$ & $14.49 \mathrm{bA}$ & $14.88 \mathrm{bA}$ \\
\hline MSDc 8.74 & MSDR $_{8} 8.16$ & & GA 24.27 \\
\hline
\end{tabular}

* Using the Tukey test, at $5 \%$ of probability, no statistical difference was found between the averages followed by the same lowercase letter in the column and capital letter in the row. $\mathrm{MSD}_{\mathrm{C}}$ and $\mathrm{MSD}_{\mathrm{R}}$ - minimum significant difference in the columns and rows, respectively; GA: general average.

The average values for soluble solids, in relation to fertilization, were significant at $1 \%$ of probability $(\mathrm{p}<0.01$; Figure 1$)$. It can be seen that the treatment with mineral fertilizer + caprine biofertilizer (T1), and the treatment with mineral fertilizer + bovine biofertilizer (T2), showed the highest values for soluble solids $\left(7.53^{\circ} \mathrm{Brix}\right.$ and $7.65^{\circ}$ Brix, respectively). As for the other treatments (T3, T4, T5 and T6), there was no significant difference among them, with values of $5.83^{\circ} \mathrm{Brix}, 5.82^{\circ} \mathrm{Brix}$, $4.99^{\circ}$ Brix and $4.48^{\circ}$ Brix, respectively. Camargo et al. (2009), studying strawberry (Camarosa and Sweet Charlie) cultivated organically, obtained values of $8.10^{\circ}$ Brix and $9.43^{\circ}$ Brix, respectively.

The soluble solids content is an important characteristic, especially for the fruit sold in natura, such as strawberries, as consumers prefer sweet fruits (Resende et al. 2010). It is worth pointing out that, according to Pádua et al. (2015), soluble solids values

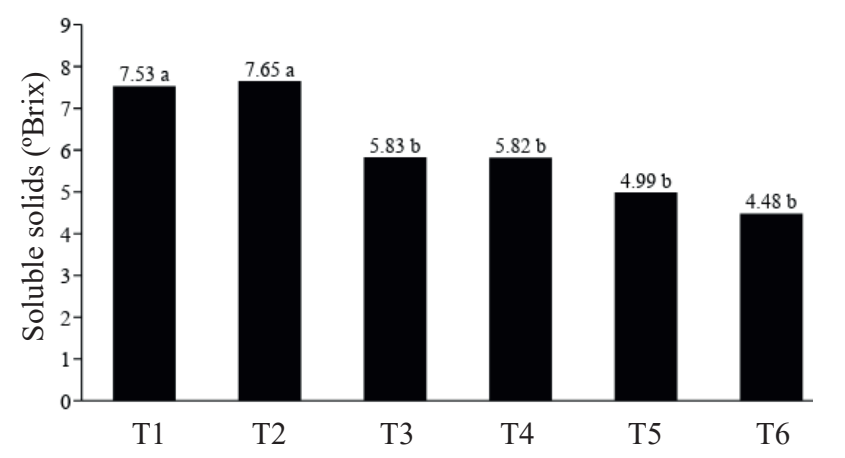

Figure 1. Average of soluble solids for strawberries, as a function of organic mineral fertilization: T1: $50 \%$ mineral + $50 \%$ caprine; $\mathrm{T} 2: 50 \%$ mineral $+50 \%$ bovine; $\mathrm{T} 3$ : $100 \%$ bovine biofertilization; T4: $100 \%$ caprine biofertilization; T5: $100 \%$ mineral fertilization; T6: control. between $4.0^{\circ}$ Brix and $11.0^{\circ}$ Brix are considered excellent for strawberries.

The average values for soluble solids related to the environments were significant at $1 \%$ of probability ( $<<0.01$; Figure 2$)$. It can be seen that the value obtained in the air-conditioned environment (6.82 ${ }^{\circ}$ Brix) was superior to those obtained in the other environments, but with a non-significant difference, if compared to the shaded environment (5.94 ${ }^{\circ}$ Brix).

In general, the protected air-conditioned environment provides better conditions for the plant development and quality, as the climatic conditions provided by this environment allows for a greater expression of the physiological activities, through a greater liquid photosynthesis and, consequently, a greater accumulation of carbohydrates, which result in an increment in the dry mass and reducing and non-reducing sugars, which, in high concentrations, improve the fruit physicochemical characteristics (Taiz et al. 2017).

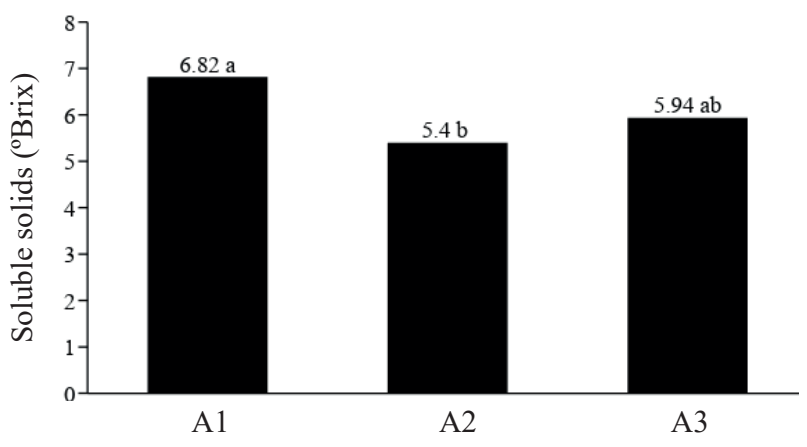

Figure 2. Average of soluble solids values for strawberries, as a function of the cultivation environments: A1: airconditioned environment; A2: full sun; A3: shaded environment. 


\section{CONCLUSIONS}

1. The highest average fruit mass per plant, number of fruits per plant and yield of strawberries cultivated under air-conditioned, full sun and shaded environments occur for the organomineral fertilization $\mathrm{T} 1$ ( $50 \%$ mineral $+50 \%$ caprine) and $\mathrm{T} 2$ (50\% mineral $+50 \%$ bovine)

2. The organomineral fertilization $\mathrm{T} 1, \mathrm{~T} 2, \mathrm{~T} 3$ (100\% bovine biofertilizer) and T4 (100\% caprine biofertilizer) show the highest averages for strawberry length and diameter;

3. The air-conditioned environment and organomineral fertilization $\mathrm{T} 1$ and $\mathrm{T} 2$ provide a better soluble solids content.

\section{REFERENCES}

ALMEIDA, M. L. B. et al. Physical evaluation of strawberries in different systems of cultures under refrigerated storage. In: BRAZILIAN CONGRESS OF MINIMAL PROCESSING AND POST-HARVESTING OF FRUITS, FLOWERS AND VEGETABLES, 1., 2015, Aracaju. Anais... Aracaju: UFS/Embrapa, 2015. p. 1-8.

BORTOLOZZO, A. R. et al. Production of strawberries in the semi-hydroponic system. Bento Gonçalves: Embrapa Uva e Vinho, 2007.

CAMARGO, L. K. P. et al. Chemical characterization of strawberry fruits cultivated in pots under organic and conventional management systems. Semina, v. 30, suppl., p. 993-998, 2009.

CASTRICINI, A. et al. Strawberries produced in the semi-arid region of Minas Gerais: quality of frozen fruit and pulp. Brazilian Journal of Food Technology, v. 20, e20161493, 2017.

COSTA, R. C. Shade screens in strawberry production in protected environment. Horticultura Brasileira, v. 29, n. 1, p. 98-102, 2011.

DIAS, C. N. Productivity and quality of strawberry under two environments and doses of biofertilizer. Brazilian Journal of Agricultural and Environmental Engineering, v. 19, n. 10, p. 961-966, 2015.

DUTRA, K. O. G. et al. The organic fertilization in the cultivation of melancholia cv. crimson sweet. Revista Brasileira de Agropecuária Sustentável, v. 6, n. 1, p. 3445, 2016.

FOOD AND AGRICULTURE ORGANIZATION OF THE UNITED NATIONS (FAO). Statistical databases. 2017. Available at: <http://faostat.fao.org $>$. Access on: 15 Feb. 2017.
KADIR, S. et al. Influence of high tunnel and field conditions on strawberry growth and development. HortScience, v. 41, n. 2, p. 329-335, 2006.

KELLER, J.; KARMELI, D. Trickle irrigation design. Glendora: Rain Bird Sprinkler Manufacturing, 1975.

LEONEL, S. et al. fertilization and organomineral fertilization: concentration of nutrients in the leaf and productivity of pine fruits. Irriga, special ed., p. 40-51, 2015.

LUZ, J. M. Q. et al. Productivity of 'Débora Pto' tomato under organomineral fertilization via leaf and drip. Horticultura Brasilera, v. 28, n. 4, p. 489-494, 2010.

MUELLER, S. et al. Tomato productivity under organic fertilization and supplementation with mineral fertilizers. Horticultura Brasileira, v. 31, n. 1, p. 86-92, 2013.

OLIVEIRA, A. M. D. et al. Production of watermelon seedlings in different environments and of fruits in the field. Ceres, v. 62, n. 1, p. 87-92, 2015.

OLIVEIRA, F. de A. et al. Initial development of castor bean under different sources and doses of organic matter. Revista Caatinga, v. 22, n. 1, p. 206-211, 2009.

PÁDUA, J. G. de et al. Behavior of strawberry cultivars in Maria da Fé and Inconfidentes, southern Minas Gerais. Revista Agrogeoambiental, v. 7, n. 2, p. 69-79, 2015.

REISSSER JÚNIOR, C. et al. Panorama of the cultivation of strawberries in Brazil. 2015. Available at: <http://www. revistacampoenegocios.com.br/panorama-do-cultivo-demorangos-no-brasil/>. Access on: 25 Sep. 2018.

RESENDE, J. T. V. et al. Productivity and soluble solids content of fruits of strawberry cultivars in protected environment. Horticultura Brasileira, v. 28, n. 2, p. 185189, 2010.

RODOLFO JÚNIOR, F.; CAVALCANTE, L. F.; BURITI, E. S. Growth and production of yellow passion fruit in soil with biofertilizers and mineral fertilization with NPK. Caatinga, v. 21, n. 5, p. 134-145, 2008.

ROSA, H. T. et al. Vegetative and reproductive growth of two strawberry cultivars under planting seasons in a subtropical environment. Journal of Agronomy, v. 44, n. 3, p. 604-613, 2013.

SÁ, F. V. da S. et al. Influence of gypsum and biofertilizer on the chemical attributes of a saline-sodium soil and the initial growth of the sunflower. Irriga, v. 20, n. 1, p. 4659, 2015.

SANTOS, A. M.; MEDEIROS, A. R. M. Nutrition, liming and fertilization. In: ANTUNES, L. E. C.; DUARTE FILHO, J. Strawberry production systems. Pelotas: Embrapa, 2005. 
SANTOS, J. L. G. et al. Cultivation of the carrot submitted to the application of doses of biofertilizer. Revista Verde, v. 12, n. 1, p. 55-60, 2017.

SCHUNCH, S. M. L.; BARROS, I. B. I. Agronomic characterization of strawberry cultivars in the region of central depression in RS. Pesquisa Agropecuária Gaúcha, v. 16, n. 1-2, p. 59-65, 2010.

SEDIYAMA, M. A. N. et al. Yield of pepper as a function of organic and mineral fertilization. Horticultura Brasileira, v. 27, n. 3, p. 294-299, 2009.

SOUSA, G. G. et al. Potassium fertirrigation in the strawberry crop in the cearense coast. Bragantia, v. 73, n. 1, p. 39-44, 2014.
TAIZ, L. et al. Plant physiology and development. 6. ed. Porto Alegre: Artmed, 2017.

TOLEDO, W. da S.; AGÁPTO, J. P.; ALMEIDA, G. F. de. Common bean (Phaseolus vulgaris L.) productivity in response to different fertilization strategies. Revista Agro@mbiente, v. 11, n. 4, p. 296-306, 2017.

VIGNOLO, G. K. et al. Production of strawberries from alternative fertilizers in pre-planting. Ciência Rural, v. 41, n. 10, p. 1755-1761, 2011.

YURI, J. E. et al. Cultivation of strawberry under different types of mulching. Horticultura Brasileira, v. 30, n. 3, p. 424-427, 2012. 